Terence C. Mills and Geoffrey E. Wood

Jerence C. Mills is a protessor at the University of Hull. Geoffey E. Wood, a professor at City University Business School in London, was a visiting scholar at the Federal Reserve Bank of St. Lowis. Kevin White provided research assistance. The authors would also like to thank Mervyn King and Paul Mizon for their helpful comments.

\title{
Does the Exchange Rate Regime Affect the Economy?
}

$\boldsymbol{I}$ wish to peg their exchange rates but sometimes have floating rates thrust upon them. On three occasions during the twentieth century - the breakup of the international gold standard in the 1930s, the breakup of the Bretton Woods system in the 1970 s and most recently the exodus of countries (notably Britain) from the exchange rate mechanism (ERM) of the European Economic Community (EEC)-external pressures led to the demise of fixed rate schemes and their replacement by some degree of exchange rate flexibility. In each case, the passing of the fixed rate scheme was mourned and within relatively short periods a new fixed rate plan was advanced to replace its fallen predecessor. In view of these failures, however, it is reasonable to ask: What makes pegged exchange rates so attractive?

Recently, in the context of the ERM, two arguments have been advanced. Exchange rate fixity is, as David Hume described in 1752 , a way of importing another country's monetary policy.' In the case of the ERM, the deutsche mark served as the system's anchor currency, and

isee Hume (1970).

2We do not consider whether a single currency really is a natural development of fixed exchange rates.

${ }^{3}$ This argument usually takes as axiomatic that trade creathon will outweigh trade diversion.
Germany's low inflation rate was supposed to spread throughout the EEC. Moreover, the ERM's member nations believed that the Bundesbank's reputation would provide some credibility to the anti-inflation commitment of other central banks and therefore reduce the costs of lowering inflation throughout the EEC. A second motive for adopting fixed exchange rates has been the claim that they, and ultimately a single currency, are important to the EEC's Single Market Programme. ${ }^{2}$ The logic is that the full benefits that could accrue from the free intra-European movement of goods, labor and capital will be realized only with a fixed exchange rate regime, ${ }^{3} A$ third argument, not emphasized recently but important on earlier occasions, is that economic performancegrowth, inflation or any other important measure-is better under a fixed exchange rate system. ${ }^{4}$ This third argument differs from the second in that it identifies no specific causal chain from exchange rate regime to economic performance.

But does the exchange rate regime matter for economic performance? That is the question

4This was an important motivation for Britain's return to the gold standard in 1925 , for example. 
addressed in this paper. We examine empirically the relationship between the exchange rate regime and a number of key macroeconomic variables to see whether any systematic relationship exists between the behavior of these variables and the exchange rate regime. We have chosen to investigate this question for the United Kingdom because data over long periods are available for the variables we wish to examine and because the United Kingdom experienced a wide variety of exchange rate regimes over the period covered by these data.

\section{TRADE AND THE EXCHANGE RATE REGIM}

The claim that exchange rate flexibility hampers international trade in goods and in capital and thus depresses welfare and perhaps growth is based on the existence of uncertainty.

It is argued that removing the possibility of exchange rate change will remove an important nontariff bartier, because the possibility of exchange rate changes will deter some traders and investors altogether, whereas others will have to pay a substantial cost to fix the domestic value of their foreign currency receipts. Floating exchange rates, in other words, are believed to impose additional volatility, and hence costs, on international markets. If this is correct, a case for pegged exchange rates exists, and the case is particularly strong for any group of countries (such as the EEC) that wants to encourage mutual intemational trade and in. vestment.

The proposition seems unexceptional, and for a number of years studies supported the proposition. For example, Cushman (1983) and deGrauwe and deBellefroid (1987), which are representative of the early literature, found that floating rates did impede trade. But as time passed, an increasing number of studies supported it. 5

By the early 1990s, not only had evidence shifted to support the notion that floating exchange rates do not impede trade, but Feldstein (1992) even went so far as to suggest that float- ing rates are more favorable to trade than are fixed rates. ${ }^{6}$ Attention is thus directed to other reasons for favoring pegged exchange rates.

There are two rather distinct types of effects of exchange rate fixing. The first arises because if a fixed exchange rate is in place, it is unlikely to stay fixed without policy actions. These can take several forms. Most common are foreign exchange intervention and short-term interest rate manipulation. Accurate figures on official intervention or the stock of foreign exchange reserves are not always available. Interest rate figures, however, are available, and several authors have found that unpredictable interest rate variability increased after exchange rates are pegged. ${ }^{7}$ These actions in turn make money growth more volatile, and this can have important consequences for the economy. It may cre ate additional uncertainty about the future behavior of the price level and thus about real rates of return, which would affect investment. If future prices were uncertain, wage bargain. ing would be more complex because it would be harder to judge the future purchasing power of an agreed money wage. This uncertainty would also affect nominal variables. Risk-averse investors would be more reluctant to buy government bonds because they would be uncertain what the coupons would be worth and what the capital would be worth at maturity. This would raise nominal interest rates, the cost of debt service and thus the taxes necessary to service the debt. All these factors could have an adverse effect on long-term growth, depressing its trend.

In summary, the choice of exchange rate regime could affect the long-run behavior of the economy, influencing trends or cycles in important macroeconomic variables.

If the choice of exchange rate regime does not have these long-run consequences, then in terms of macroeconomic effects, all that the choice of exchange rate regime does is shift the distribution of short-run fluctuations from one market to another. This is the second type of effect noted above.

The question we examine is whether any as-

\footnotetext{
5Examples of these studies are Gotur (1985); the IMF's (1984) extension of Cushman (1983) to cover the bilateral trade of the seven largest industrial countries; Bryant (1987), Bailey, Tavlas and Ulan (1986 and 1987), Bailey and Tavlas (1988) and Ascheim, Bailey and Tavlas (1987).

6Haberler (1986) suggested the same thing some years earlier.
}

7See Batchelor and Wood (1982), Wood (1983) and Belongia (1988). Wood and Belongia's research was conducted in the context of the ERM. In Wood (1983) there was an exception to this-Erie (South lreand) atter it joined the ERM. Unpredictable interest rate variability fell in that country, although it increased in every other ERM member country. 
sociation exists between the exchange rate regime and the trend or cyclical behavior of some key macroeconomic variables-in other words, whether there is any evidence for the first type of effect. If no such association exists, then the only macroeconomic consequence of the choice of exchange rate regime is the change in the distribution of short-term volatility between the foreign exchange market and the short-term money markets. If, in contrast, such an association exists, then the choice of exchange rate regime may be a macroeconomic policy decision. of considerable importance for national wellbeing. ${ }^{8}$

It is now appropriate to present the data we use for exploring this question. We then examine the properties of those data in light of the preceding discussion.

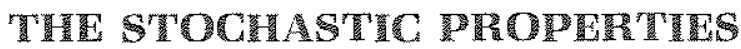 OF U.K. MACDORCONOMTC SERTES

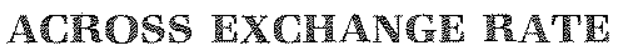 PEGIMTS}

In this section we consider the stochastic properties of five major U.K. macroeconomic series since the mid-nineteenth century. The exchange rate regimes since then have encom. passed every possible type except the crawling peg. Until 1914, the United Kingdom was on the gold standard. That was suspended (that is, the United Kingdom left the standard but with the declared intention of returning) at the outbreak of World War I in 1914. After the war, the United Kingdom implemented a deliberate, discussed and announced policy of a return to the gold standard at the prewar parity. Monetary policy and foreign exchange intervention were used to this end, and the policy succeeded in 1925. The United Kingdom left the gold standard in 1931, however, and the exchange rate floated with varying degrees of intervention un. til the outbreak of World War II in 1939." The rate was then pegged to the U.S. dollar. After the war, the United Kingdom joined the Bretton Woods system. Several sterling devaluations occurred under Bretion Woods, but sterling did not finally float until 1972. Again, there were varying degrees of intervention under this regime of dirty floating, but the United Kingdom did not formally peg sterling until it joined the ERM in 1990 after shadowing the deutsche mark in 1988 and 1989. The United Kingdom stibsequently left the ERM in 1992 to float once more. The series we examine across these various regimes are output, prices, money, and short- and long-term interest rates.

Our particular interest, and the focus of the empirical work that follows, is the trend and the cycle in output and prices primarily, but also in money and interest rates. We look to see how these variables have behaved over our close to a century-and-a-quarter of data, seeking changes in trend and changes in cyclical pattern. When these are identified, we examine whether any of these changes are associated with exchange rate regime changes and, if so, consider why this might be.

\section{Outpere}

Annual output in the United Kingdom (measured in logarithms) over the period 1855-1990 is shown in figure 1. Detailed econometric analyses of this series in Mills (1991) and Mills and Wood (1993) show that it can be represented as the sum of a segmented linear trend, with breaks at 1918 and 1921 and a stationary, autoregressive, cyclical component. ${ }^{\text {To }}$ Thus these results indicate that if output can be decomposed as $y_{t}=\mu_{f}+n_{t}$, then the trend function $\mu_{f}$ is

(1) $\mu_{t}=\alpha+B t+\lambda_{1} D_{n}+\lambda_{2} D_{2 t^{\prime}}$

where $D_{i t}=\left(t-T_{i}\right)$ if $t>T_{i}$ and zero otherwise. The identified breakpoints are at $T_{1}=64$ and $T_{z}=67$, which coincide with 1918 and 1921. The cyclical component, $\mathrm{n}_{r}$, on the other hand, is found to be adequately modeled as an $\operatorname{AR}(2)$
Eit is, of course, possible that the exchange rate regime is a product of the behavior of the economy; it need not be an exogenous choice.

sFor a review and evaluation of explanations that have been advanced to explain the United Kingdom's abandonment of the gold standard, see Capie, Mills and Wood (1986a).

10 Testing for stationarity has no direct economic significance. Rather, it lets us separate the cycle from the trend. The notion is that the trend and the cycle are economically separate. The cycle comprises fluctuations about a horizon* tal average; growth is all in the trend. This separation is consistent with most views of the cycle, but it should be noted that some scholars see the cycle as an integral part of the growth process. For an example, see Schumpeter (1950). 
Figure 1

Annual U.K. Output (1855-1990)

Logarithms

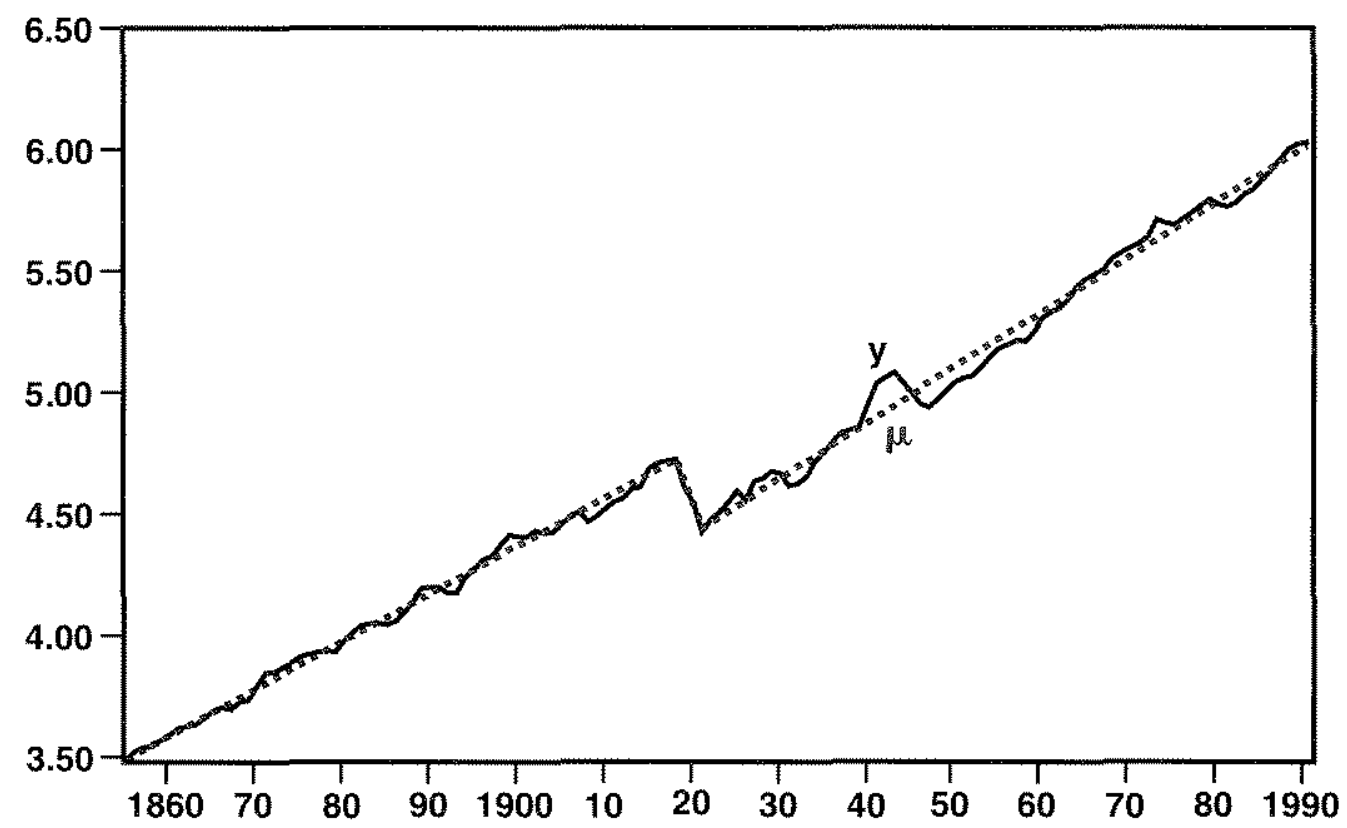

process, leading to the fitted model (standard errors shown in parentheses),

$$
\begin{aligned}
& \text { (2) } Y_{t}=3.474+0.0196 t-0.1137 D_{1 t}+ \\
& (0.026) \quad(0.0007) \quad(0.0103) \\
& 0.1170 D_{3 t}+n \\
& \text { (0.0101) }
\end{aligned}
$$

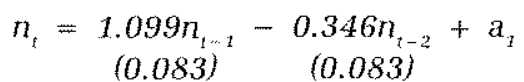

This model has some simple properties. Trend growth is 1.96 percent per year until 1919 and 2.29 percent per year from 1922 on, with the level of trend output falling 28.3 percent in the intervening three years. The component $n_{t}$ implies that output exhibits stationary cyclical fluc. tuations around the trend growth path, with cycles averaging 8.1 years. The residual standard error of the equation is 2.33 percent.

The trend component is shown superimposed on the output series in figure 1 , and we thus conchude that, apart from the three years immediately after World War 1, during which the series fell dramatically, the stochastic process generating oufput has remained remarkably sta* ble. Output is a trend stationary process, irrespective of the exchange rate regime in force.

\section{F}

Figures 2 and 3 present plots of the (logarithmic) U.K. price level anmually from 1870 to 1990 and monthly from January 1922 to May 1992, respectively, excluding the war years from 1940 to 1945 . Unit root tests, calculated over various sample periods, provide little or no evidence against the hypothesis that prices are difference stationary, that is, I(1)." The post 1973 era may differ and is discussed later.

Two aspects of price behavior are worth fur.

\footnotetext{
1tDetails of these tests and similar tests for the other series
} investigated are reported in Milis and Wood (1993). 
Figure 2

Annual U.K. Price Level (1870-1939)

Logarithms

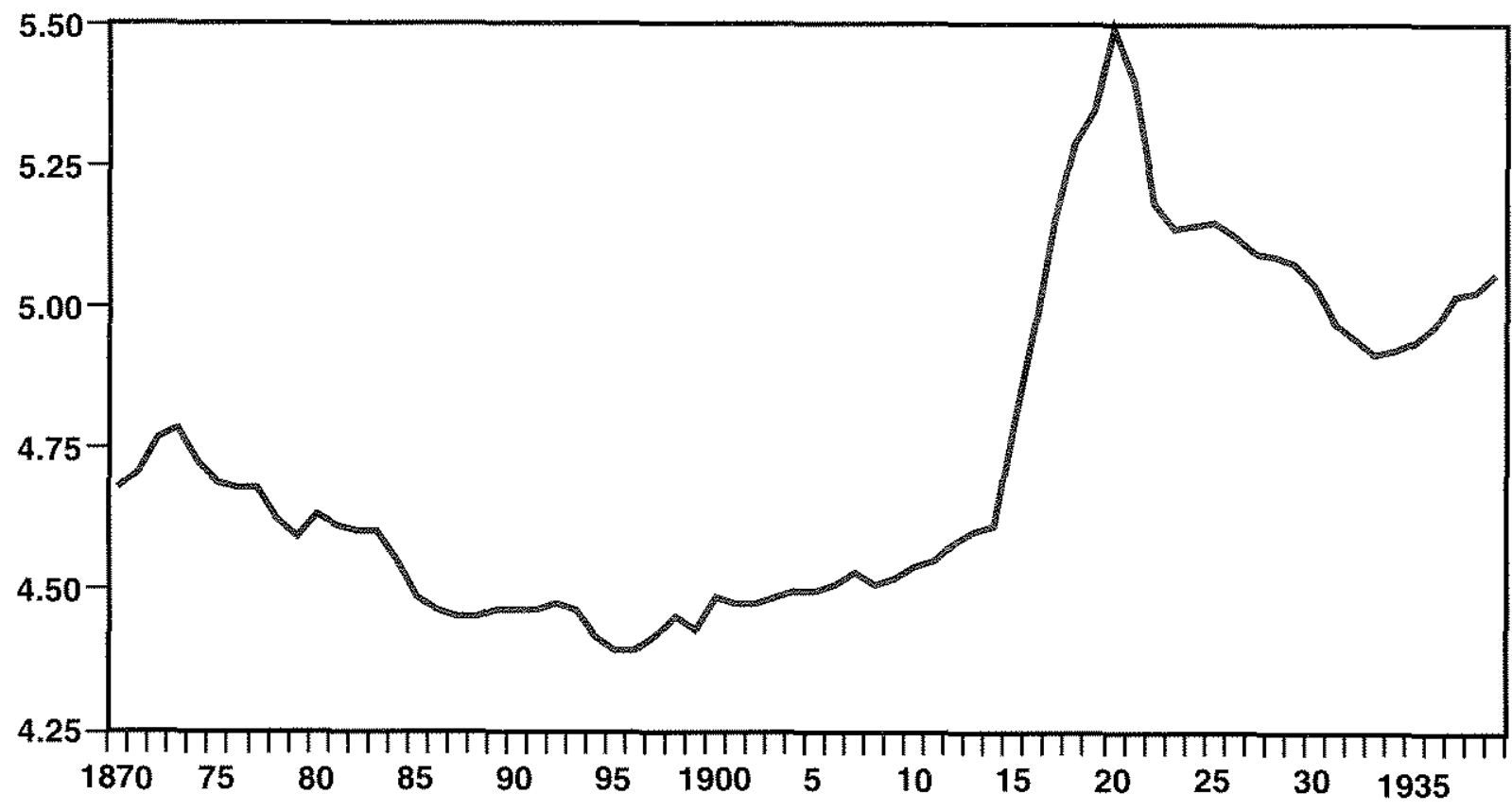

Annual U.K. Price Level (1946-1990)

Logarithms

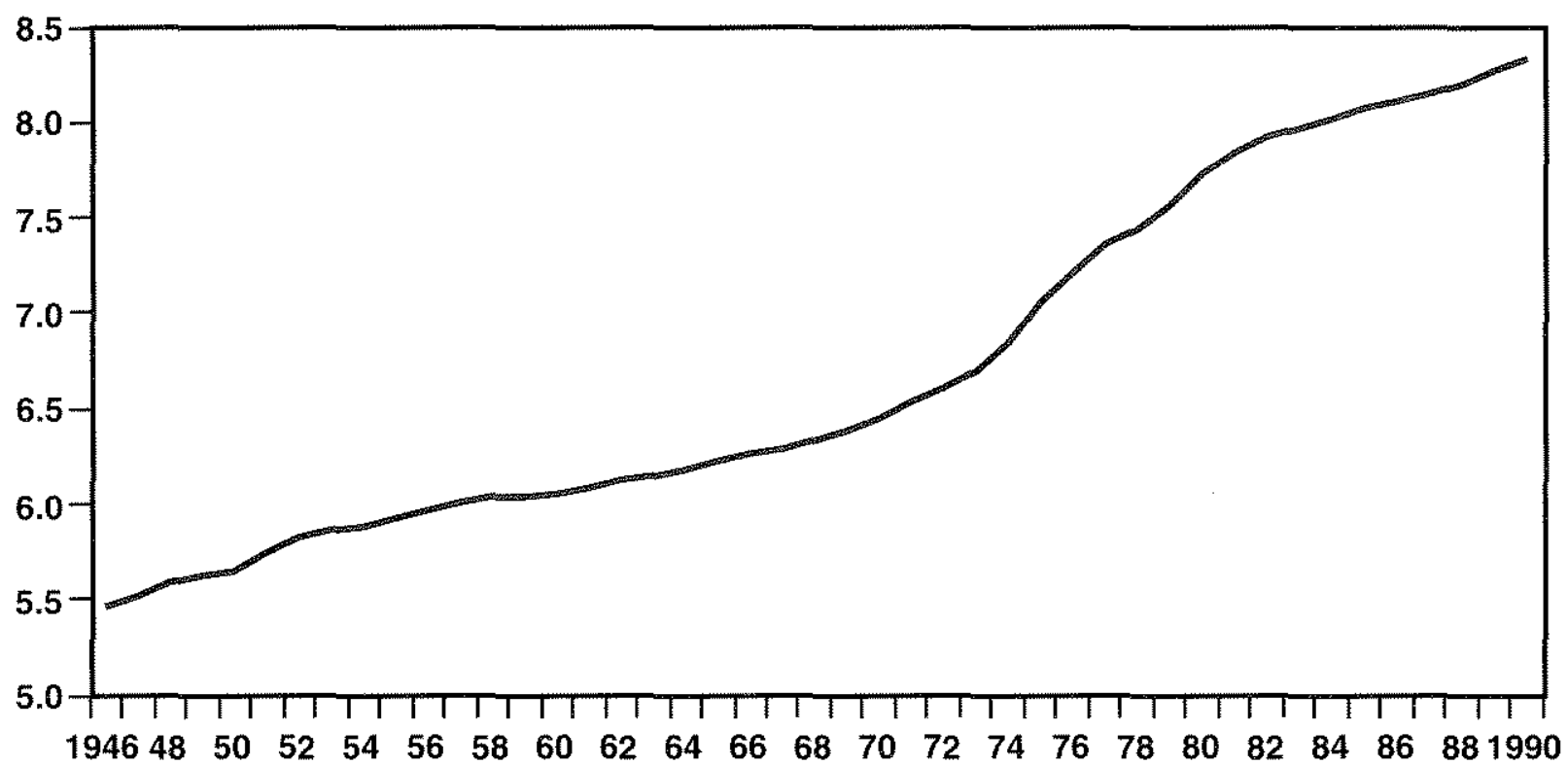


Figure 3

U.K. Price Level (1922-1939)

Logarithms

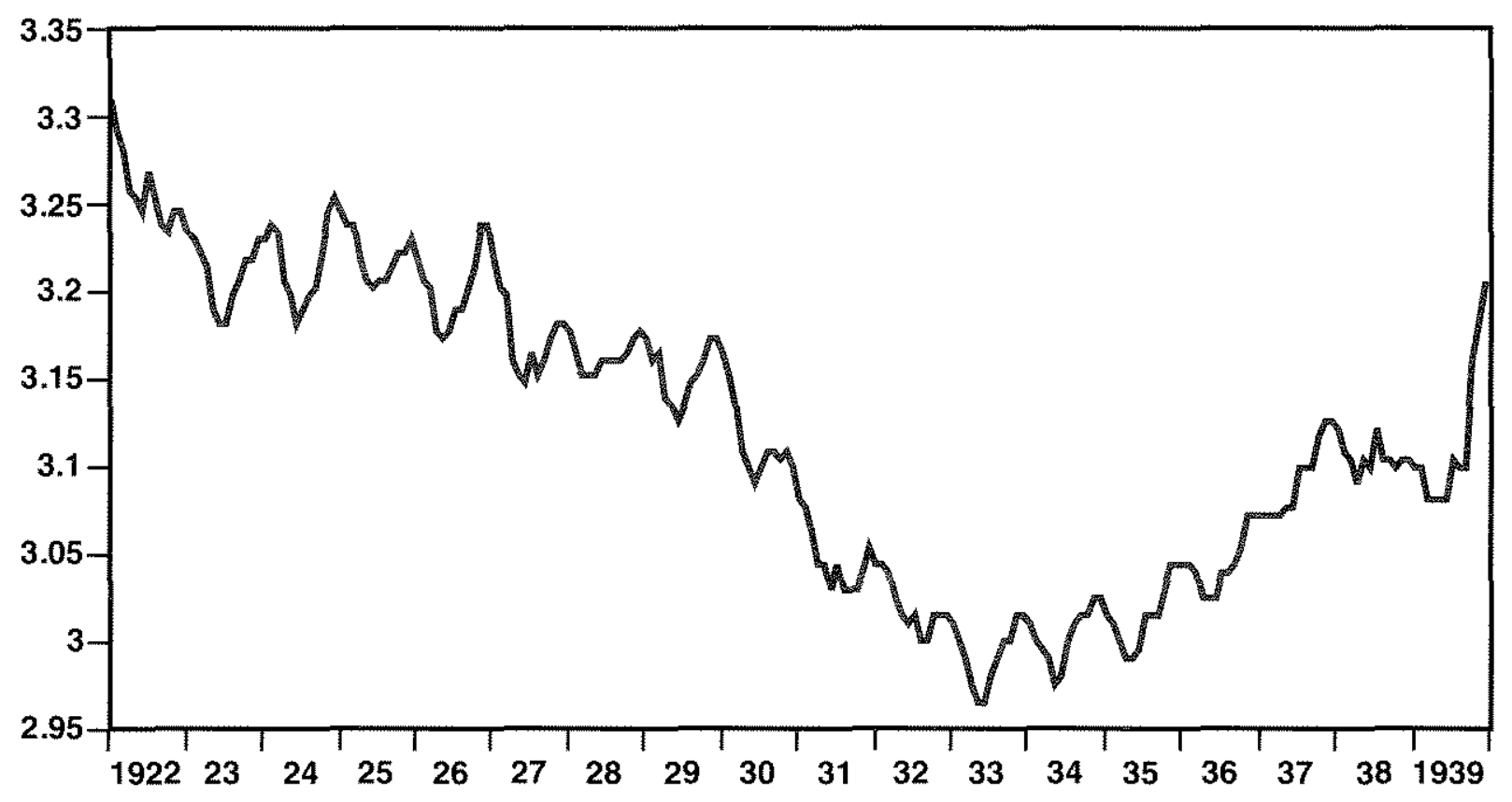

U.K. Price Level (1946-1992)

Logarithms

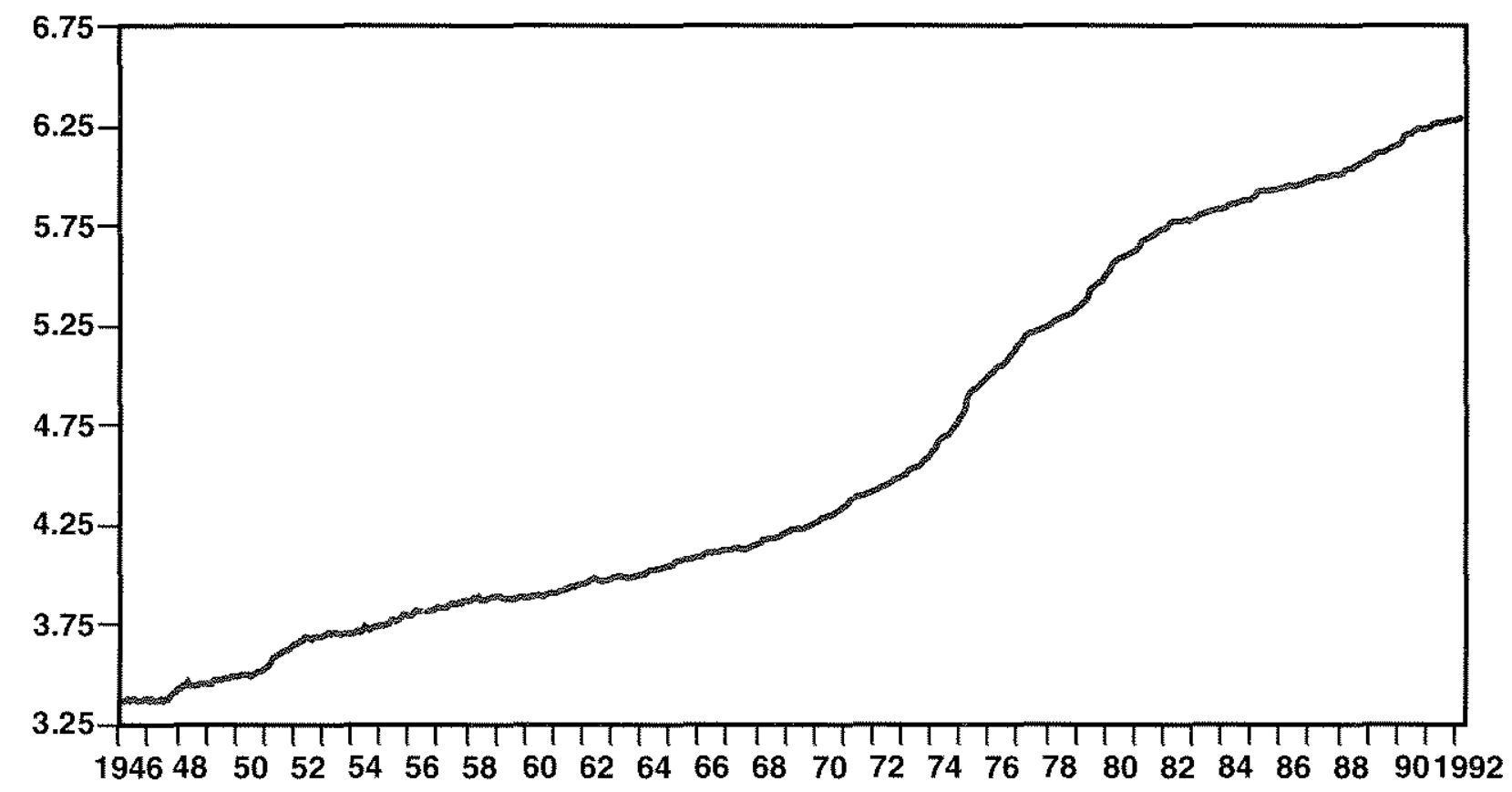


ther investigation. The first is the behavion of the price level before the United Kingdom abandoned the gold standard in 1931. Mills (1990) analyzes the long gold standard period from 1729 to 1931 and obtains an estimate of the largest autoregressive root of 0.93 , identical to that obtained for the shorter sample beginning in 1870. The corresponding unit root test, though, rejects the unit root null hypothesis at the 5 percent significance level, and the process found to generate the price level (an autoregression of order twol yields cycles of around 50 years, close to the long swings thought to have characterized prices during this period. ${ }^{ \pm 2}$

The second aspect concerns the post-1946 behavior of prices. Figures 2 and 3 show the series to have undergone slope changes around 1973 and 1983; possible explanations for these are discussed in the next paragraph and in the Interpretation and Conclusions section. Statistically, this behavior is typical of an I(2) process, and repeating the unit root tests for the (logarithmic) price changes, that is, for inflation, yields some evidence that postwar prices can be modeled as an I(2) process (evidence that inflation is nonstationary), particularly for the postBretton Woods era beginning in 1973 .

The results are therefore suggestive of the U.K. price level undergoing two shifts in its generating process. The first might be associated with the abandonment of the gold standard, shifting the series from I(0) to an I(1) process. (From figure 3 it is in fact clear that prices did not start a secular increase until mid-1933, some two years after the move from the gold standard.) ${ }^{* 3}$ A stable price level is certainly in accordance with what would be expected under the gold standard (or, in principle, any commodity standard). There were fluctuations in the supply of gold, but in countries such as the United Kingdom, which had developed and stable banking systems, these fluctuations had only modest price level effects. The system was to some extent self-stabilizing. If prices were falling (the value of money rising) because the supply of gold was falling short of demand, there was an incentive to produce more gold. And if prices were rising (the value of money falling), then as the costs of gold production rose relative to what the monetary authorities would pay for

12See Cagan (1984) for an extended discussion of this view.

13 See the discussion in Capie, Milss and Wood (1986a).

${ }^{14}$ See Barro (1979) and Fockoff (1984) for a discussion of this. gold, the incentive to produce gold would diminish. ${ }^{34}$ The second shift is around 1973 and could be associated with both the move to floating exchange rates and the first oil price shock.

\section{Money}

Figure 4 plots annual observations of the logarithms of M3 from 1871 to 1912 the only aggregate apart from the monetary base available for this period), and figure 5 plots monthly observations of M3 from 1922 to 1989 , exclud. ing the war years. From a battery of unit root tests, we found that, for all sample periods investigated, the null hypothesis of a unit root cannot be rejected. Moreover, the series is indeed I(1) because we could not establish that further differencing was required for stationarity.

\section{Interest Rates}

Figures 6 through 8 plot monthly observations of short-and long-term interest rates from 1870 to 1992 , excluding war years and related periods of interest rate restrictions.

From the results of unit root tests, we find that since the lifting of restrictions after World War II both short- and long-term interest rates have been I(1) processes, but their behavior before 1939 is rather different. Both are stationary between 1932 and 1939, but during the 1920 s long-term rates are stationary (I(0)) and short-term rates are I(1), whereas before 1914 the orders of integration are reversed. ${ }^{15}$

\section{Trend and Cycle Decompositions}

Has the variability about trend of the series altered across regimes? This is an important question because of the widespread belief that floating exchange rates increase volatility in prices, interest rates, and economic activity and are in some general sense destablizing. To an" swer this question, we need to decompose each series into trend and cycle components. There are many ways to do this, ranging from using a predetermined moving average to calculate trend to designing a signal extraction filter based on the stochastic process generating the data and a set of assumptions relating to the behavior of the unobserved components.

${ }^{15}$ Capie, Mills and Wood (1986b) provides an extended dis cussion of the behavior of these two interest rate series in relation to the Stock Conversion of 1932 . 
Figure 4

Annual U. K. Money Supply: M3 (1871-1912)

Logarithms

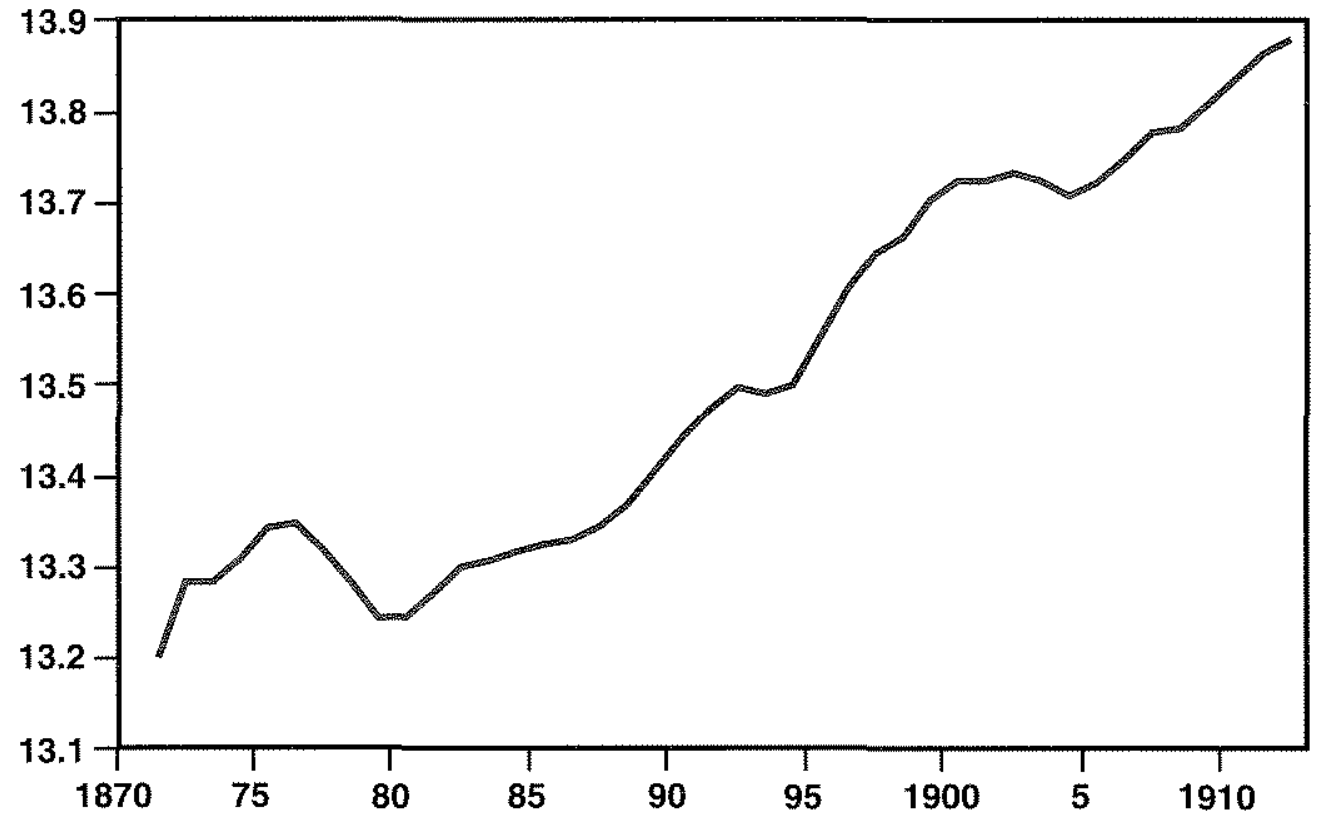

For output, equation (1) provides the appropri* ate decomposition. Table 1 thus reports the standard deviations of the cyclical component $n_{i}$ for a variety of sample periods. The sample periods shown were chosen by two quite distinct criteria-output trend change and exchange rate regime alteration. The 1922 break was used because after the 1919-22 discontinuity, output resumed a new trend, 1855-1913 were gold standard years, and $1925-31$ were years during which the United Kingdom was either on or committed to returning to the gold standard. The period comprising $1855-1913$ and $1922-31$ is the same period omitting war and the postwar years of the break in output's trend. The period $1922-31$ has a stable output trend combined with commitment to gold; the period 1922-39 has a stable output trend with a change in exchange rate regime. 'The period $1932-90$ is our whole sample period after gold. The years 1932-39 and 1946-90 are, of course, the same period excluding the World War II years. The period $1946-90$ is simply postwar; $1946-72$ is Bretton Woods; and $1973-90$ is the period of various degrees of float. (Further subdivision of the series to examine the association with various exchange rate regimes more minutely, although appealing, is muled out by many of these regimes having too few output observations for our statistical techniques.) From all these statistics, one gets the impression that variability about trend has increased during the twentieth century. In particular, the aban donment of the gold standard in 1931 seems to have been accompanied by an increased variability of output about trend, even after the war years are excluded. In summary, the standard deviation almost doubled (from 2.87 percent to 5.49 percent) after 1931 . But it should be noted that variability fell after the pound floated in 1972. From 1946 to 1972 the standard deviation was 4.45 percent; from 1973 to 1990 it was 3.64 percent.

For the other series, we have presented evidence of shifts in the stochastic processes generating them, so signal extraction techniques would be rather difficult to apply. We have chosen therefore to use a technique that has proved popular in recent years for reexamining the stylized facts of macroeconomic time series, namely the detrending filter proposed for use in economics by Hodrick and Prescott and used, 
Figure 5

U.K. Money Supply: M3 (1922-1939)

Logarithms

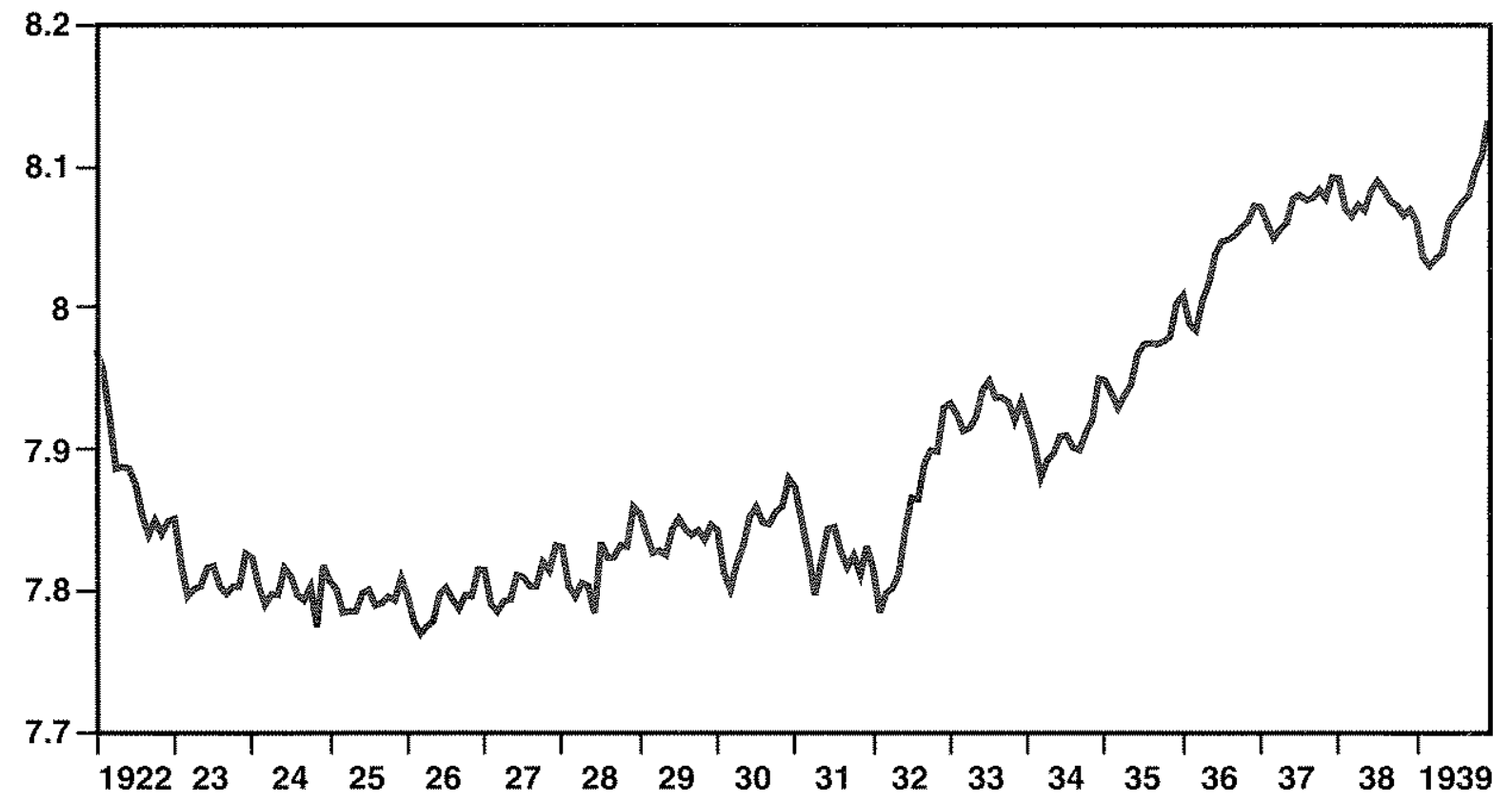

U.K. Money Supply: M3 (1946-1989)

Logarithms

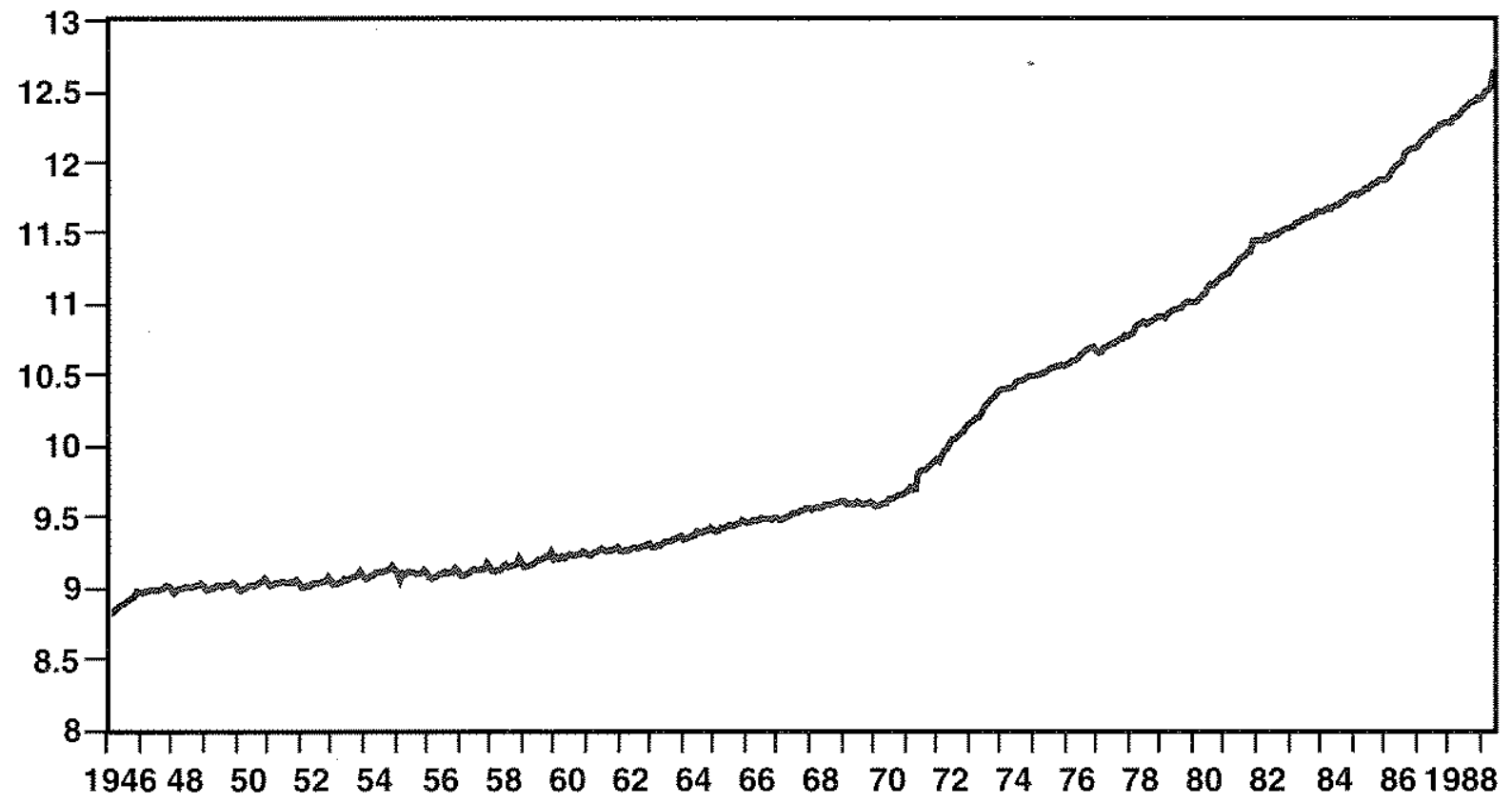


Figure 6

U.K. Interest Rates (1870-1913)

Percent

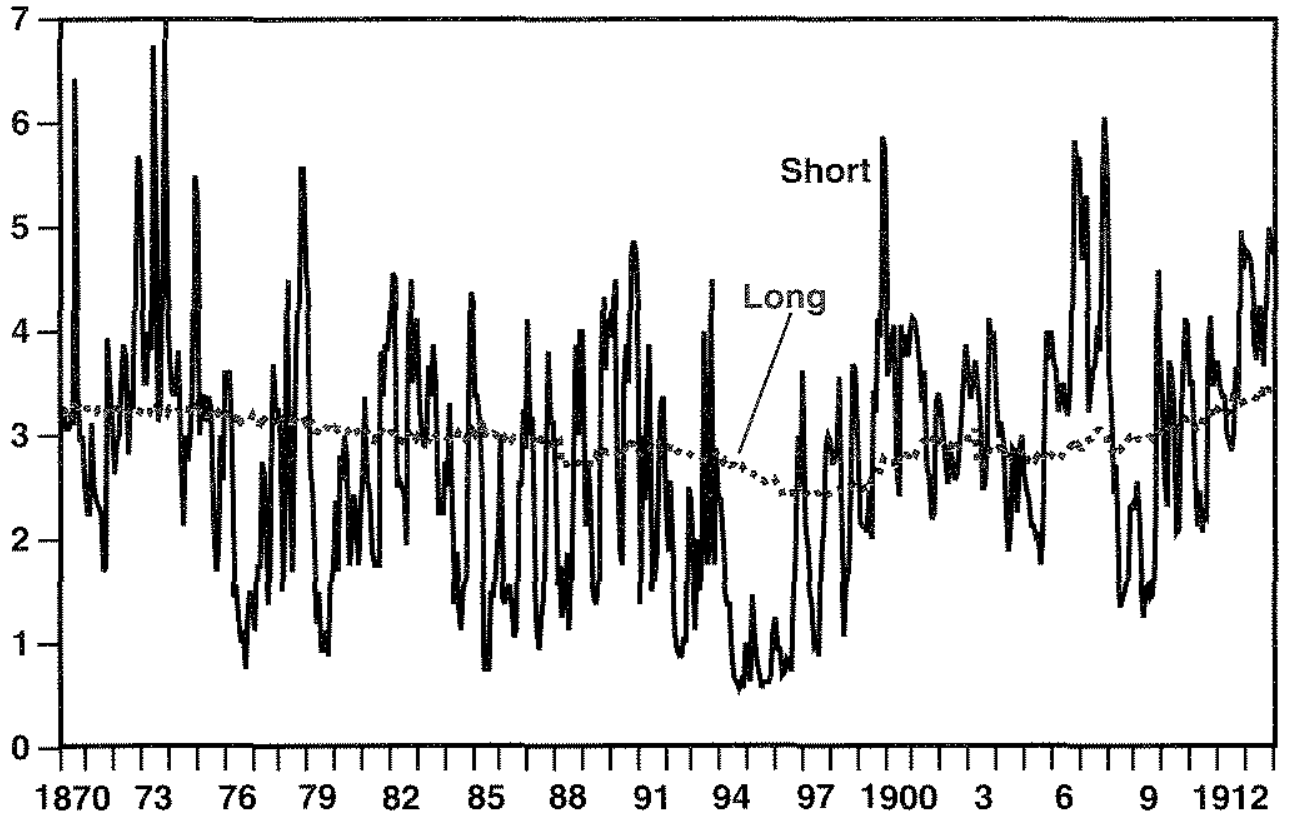

Figure 7

U.K. Interest Rates (1922-1939)

Percent

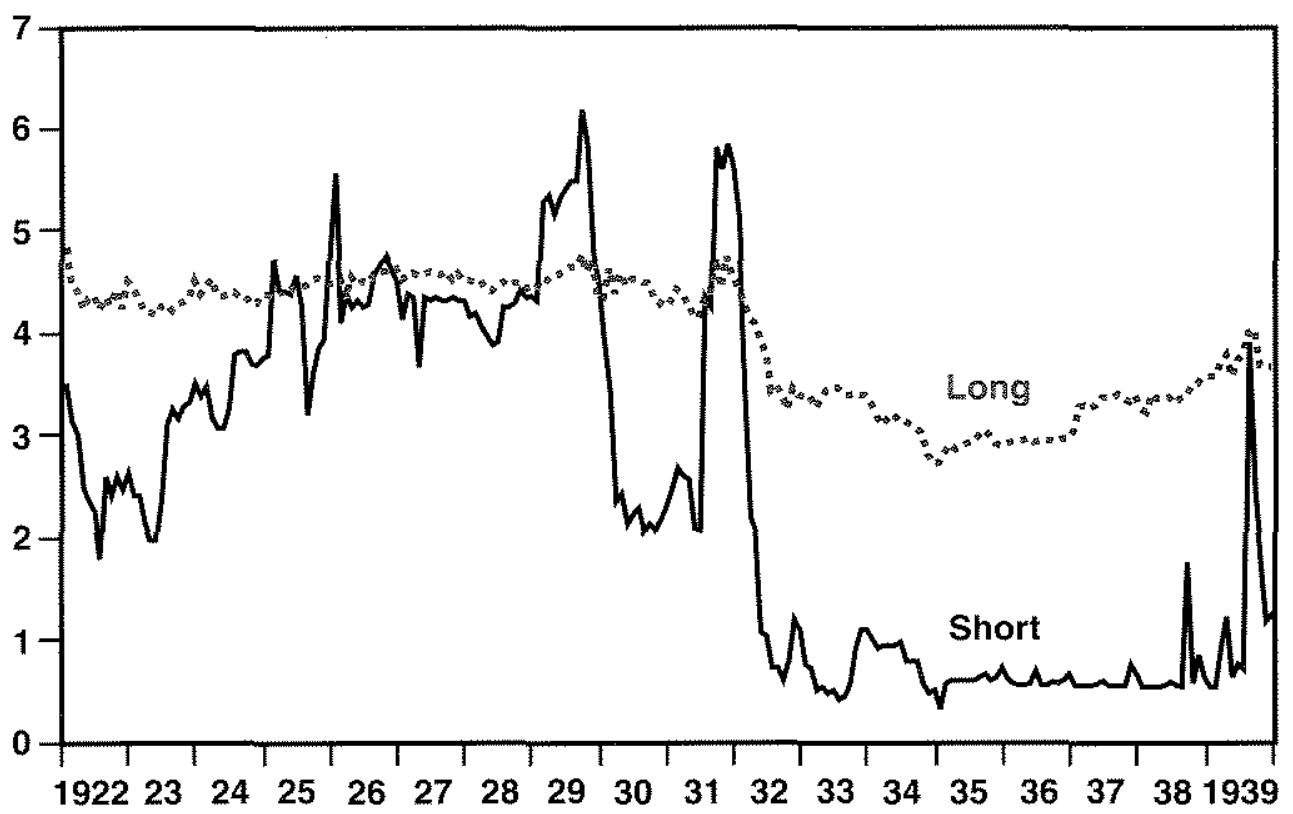


Figure 8

U.K. Interest Rates (1954-1992)

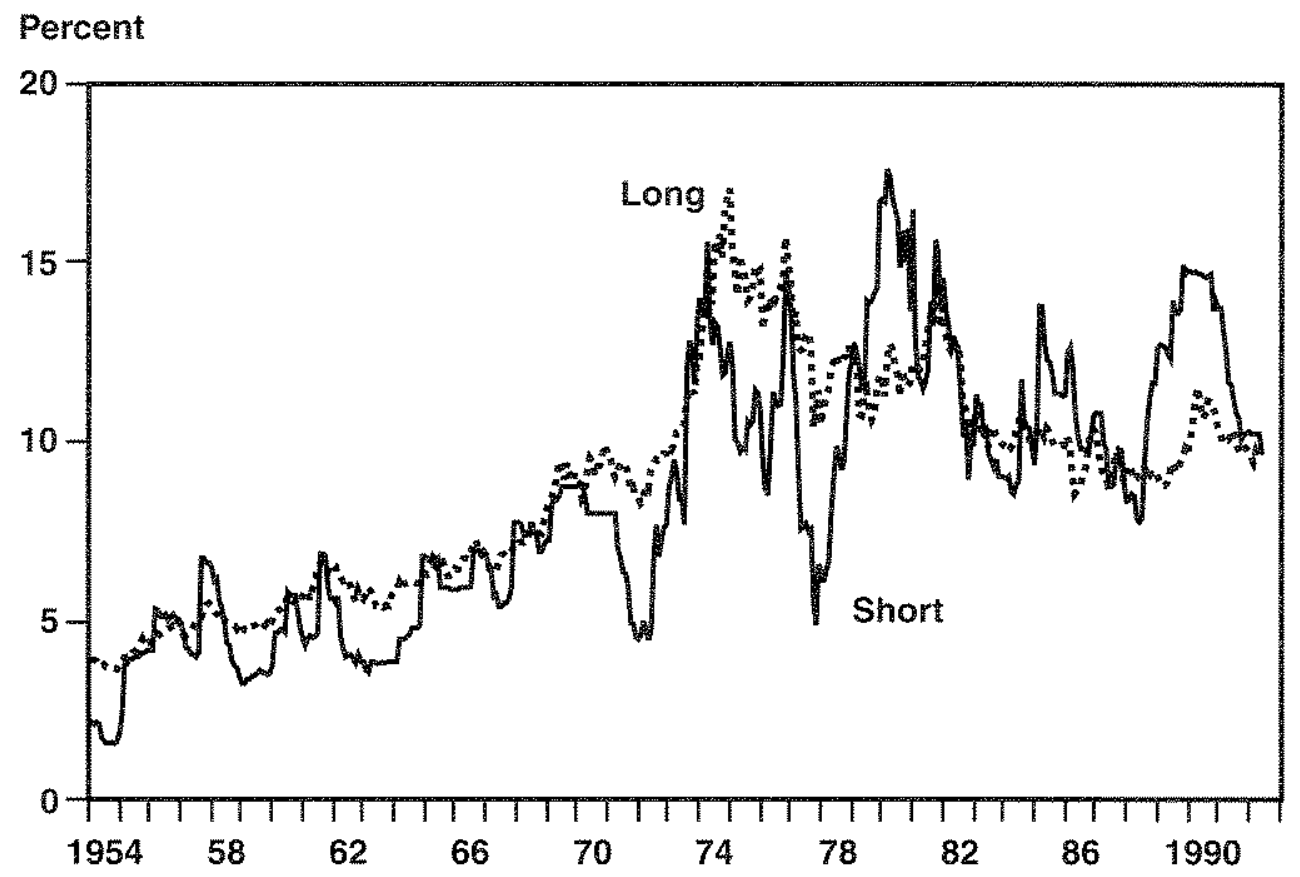

for example, in Kydland and prescott. 1 "This is an attemative to the method used earlier in the paper for separating a series into trend and $c y$ cle. It is described in the appendix, which also contans a summary of when this method is appropriate and when it may be misleading.

Tables 2 through 5 report statistics assessing the variability of the trend and cycle components of the price level, money supply and short-and long-interest rates, and figures 9 through 12 present graphs for these components. Although these tables report results from the examination of monthly data, the breakpoints are at year ends except for 1992, whose data end with June.

This choice of breakpoints reflects two considerations. The first relates to when an exchange rate regime changed. Does change for our purposes relate to when the change was formally announced or to when it became expected and affected behavior? The latter is the more significant, but it is not clear a priori when it would be Nor as it turns out does detailed examination of the data case by case give clear-cut answers. ${ }^{17}$ Acordingly, the simple expedient of using calendar years as break. points was adopted, on the grounds that using other dates close to these would not change the results.

For the interwar years, the trend of the price level was relatively flat, with a slow decline until 1933 and an upward drift thereafter. The cyclical component, in contrast, is relatively volatile, no doubt, in view of the unchanged behavior of money, reflecting the changes in exchange rate policy in the United Kingdon, as well as the disturbed external environment. Not only did the interwas years include the Great Depression in the United States, with the associated severely depressing effects on the prices of commodities, but in continental Europe there were inflations-hyperinflations in some cases-civil war and revolutions. Meanwhile Britain's exchange rate regime was chang. ing rapidly. Between 1919 and 1925 there was a 


\section{Table 1}

Variability of the Cyclical Component of Output

r
r

Table 2

\section{Component Variability of Prices}

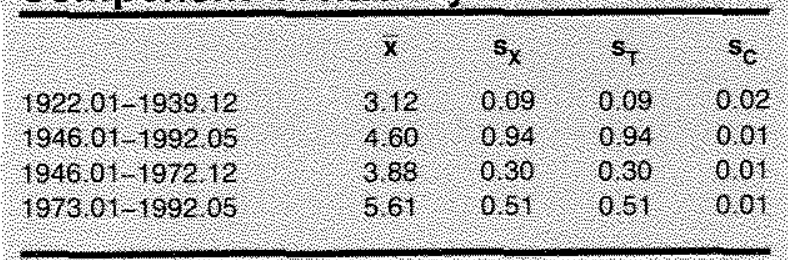

\% 4 ample nean

8, 6 angle standaro devalion

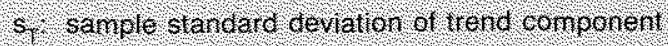

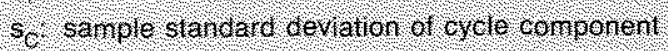

commitment to return to gold at the prewar parity, and the exchange rate rose steadily toward that. Gold was abandoned in 1931, and the exchange rate thereafter floated with various degrees of intervention until the outbreak of war in 1939.

After 1946 , the trend is smooth and monotonic, and the cyclical component is less volatile than before. Trend money is rather similar to trend prices. Its variability is stable throughout the sample period, supporting the suggestion that external factors were important in interwar price volatility.

Pre-1914 trend interest rates fluctuate around
Table 3

Component Variability of Money

\begin{tabular}{|c|c|c|c|c|}
\hline & $x$ & $s_{8}$ & s) & $s_{C}$ \\
\hline $192201-193912$ & 790 & 0.10 & 0.10 & 0.02 \\
\hline $194601-199205$ & 10.04 & 1.08 & 1.08 & 0.62 \\
\hline $996,01-1972,12$ & 9.27 & 0.27 & 0.27 & 002 \\
\hline $107301,1989.06$ & 1,29 & 0.67 & 0.67 & 0,02 \\
\hline
\end{tabular}

x. sample nean

9. sample standard doviallon

s, sumple standard devirtion of trend component

se sornple standard devigtion of oy cle component

Table 4

\section{Component Variability of Short-Term Interest Rates}

\begin{tabular}{|c|c|c|c|c|}
\hline & $\mathbf{x}$ & s, & 5, & $s_{C}$ \\
\hline $1870.01-191312$ & 279 & 121 & 077 & 088 \\
\hline $192201-1931,12$ & 3.75 & $10 \%$ & 0.68 & $0 \% 6$ \\
\hline $193201-190912$ & 0.86 & 071 & 0.5 & 0.53 \\
\hline $1954.01-197212$ & 5,62 & 176 & 154 & 0.66 \\
\hline $197301-199201$ & 11,48 & 2.4 & 1884 & $\sqrt{22}$ \\
\hline
\end{tabular}

1. sanple nean

5. Sample slaticard devielion

Sp sample standard cevition of trend eompenent

s. sample standard deviation of cycle component

3 percent, although the far greater stability of long-term rates is reflected in the almost constant components of this series relative to shortterm rates. ${ }^{18}$ Volatility is indeed fairly stable until 1972, after which both trend and cycle components became considerably more variable.

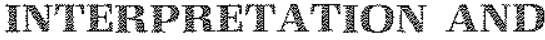 CONGUSTONS}

When discussing the preceding findings, it is convenient to consider the trend and cyclical behavior of each series together. We start with output. As noted previously, the trend growth

and Wood (1992) was unable to reject this hypothesis after exhaustive testing.
We have noted this result in a series of previous papers.
Mills and Wood (1982) suggested it was due to the stable price expectations provided by the gold standard. Milis 


\section{Table 5}

\section{Component Variability of Long-Term} Interest Rates

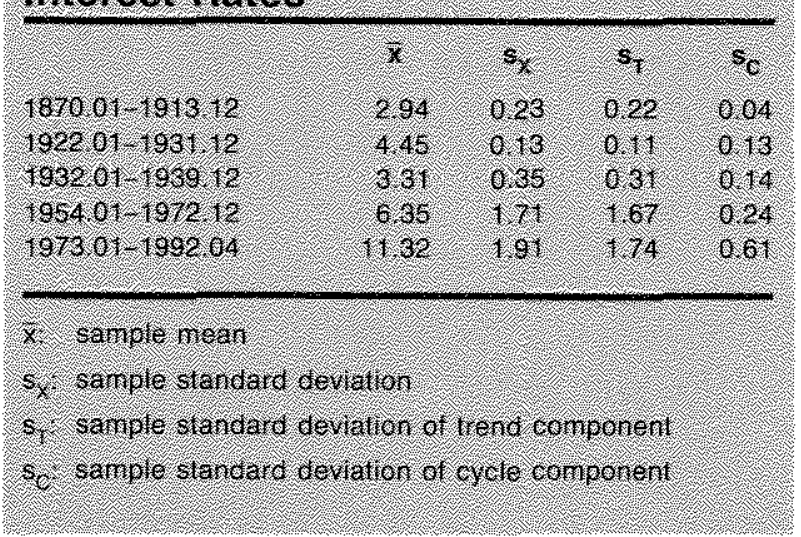

of output changed from 1.96 percent per year to 2.29 percent per year between 1919 and 1922. Speculating on what produced that welcome change is outside the scope of this paper. What we would note is the stability of the post-1922 trend in the face of a wide variety of monetary experiences and exchange rate regimes, a finding clearly consistent with the long. run neutrality of money.

In contrast to that long-run neutrality, the cyclical behavior was affected. The variability of output rose substantially with the abandonment of the gold standard. The significance of this is discussed later.

Turning now to prices, what do we find? The first notable feature is the essentially flat trend, with long swings around it, under the gold standard. More dramatic and equally revealing about the nature of the monetary regime is the post-1946 period. The trend of prices was positive after 1946, accelerated sharply around 1973 and slowed around 1983. The United Kingdom went to a floating exchange rate in 1972 , but at around the same time there was also the first oil price shock and the Heath-Barber monetary expansion. That the acceleration of prices was the result of these factors rather than the new exchange rate system is suggested by the slowing of prices around 1983, when the United
Kingdom was still under a floating rate regime but had a government strongly committed to reducing inflation by introducing money supply targets and a commitment to budget balance over the cycle. ${ }^{19}$ The cyclical component of prices became much smoother and was unaffected by the exchange rate regime; its variability was unchanged from 1946 to 1992 and identical over subperiods and the period as a whole.

And finally, interest rates. The striking contrast is between the behavior in the pre-World War II period, when long-term rates were stable and short-term rates were volatile, an observation usually interpreted as reflecting expectations of long-run price level stability and behavior in the post-1972 period, when inflation first accelerated and then slowed, and both interest rate series displayed markedly increased variability. ${ }^{20}$

How do these findings as a whole bear on the hypothesis that the exchange rate regime is not a source of volatility? They support it. Of the variety of exchange rate regimes after 1913 (we turn to the gold standard in a moment), none seemed to increase the volatility of any series examined to any significant extent. The policy changes mecessary to hold rates pegged may have appeared in foreign exchange reserves, a series that we did not examine because reliable data were not avallable. The policy changes did appear in movements that had higher frequen. cies than the trends and cycles we isolate. ${ }^{2 k}$ Interest rate cyclical variability did increase with the move to floating exchange rates in 1972 , but there are numerous other factors to explain this. Shocks to the price of oil disturbed financial markets very substantially in this period. Two other shocks were superimposed on the oil price shocks. There was a commitment to reduce inflation-particularly after 1979. What this meast in terms of the operation of monetary policy was unknown, so the commitment increased uncertainty for a time. And further, monetary targets were adopted. These affected how the authorities used short-term interest rates; and as commitment to monetary targets

19The role of the exchange rate regime in the 1970 s episode is also discussed in Williamson and Wood (1976). The conclusion that the exchange rate regime was not at fault was also, by different means, argued there.

zoSee Mills and Wood (1982). Fisher (1930), Friedman and planations of the Gibson paradox that depend on slowmoving price expectations.

27 See Batchelor and Wood (1982), Wood (1983) and Belongia (1988). 
Figure 9

Price Level Trend and Cycle (1922-1992)

Logarithms Logarithms

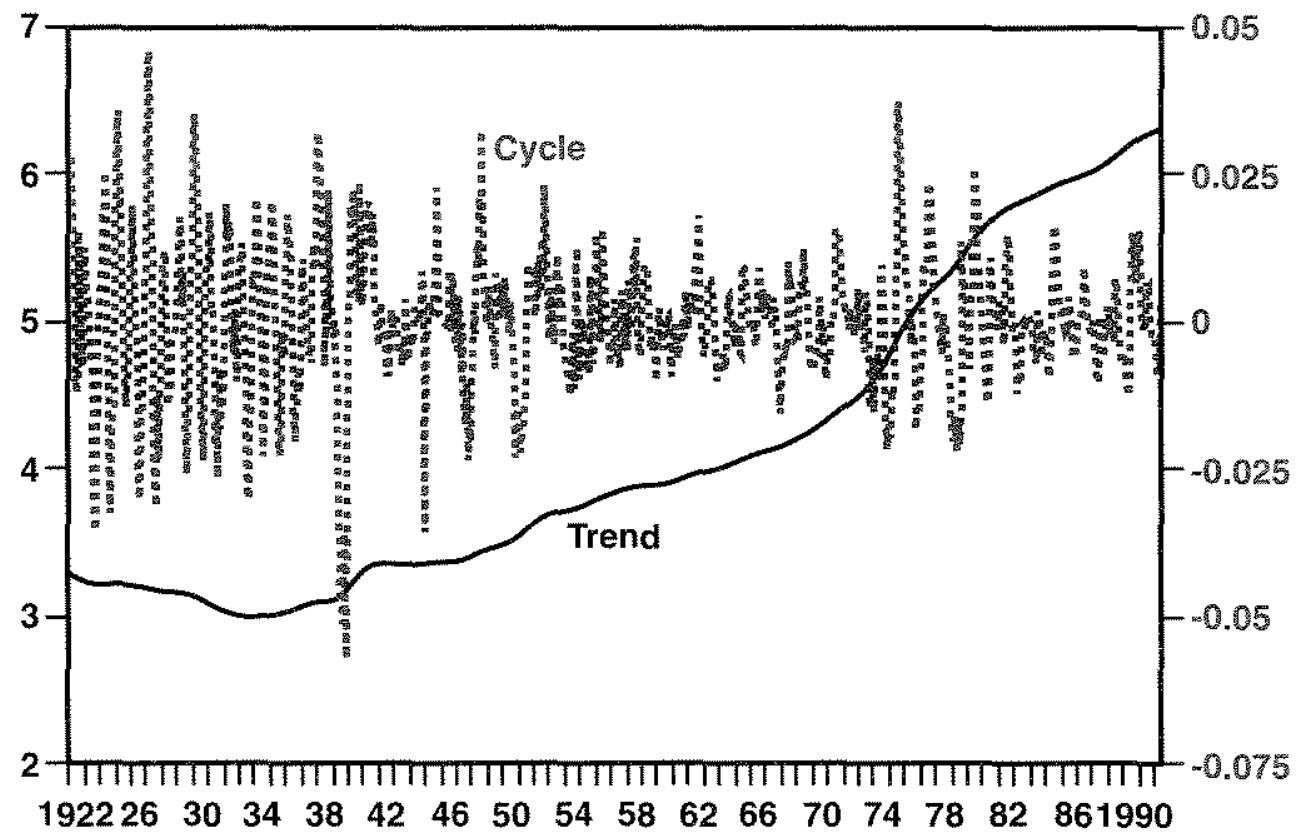

Figure 10

Money Supply: M3 Trend and Cycle (1922-1989)

Logarithms

Logarhhms

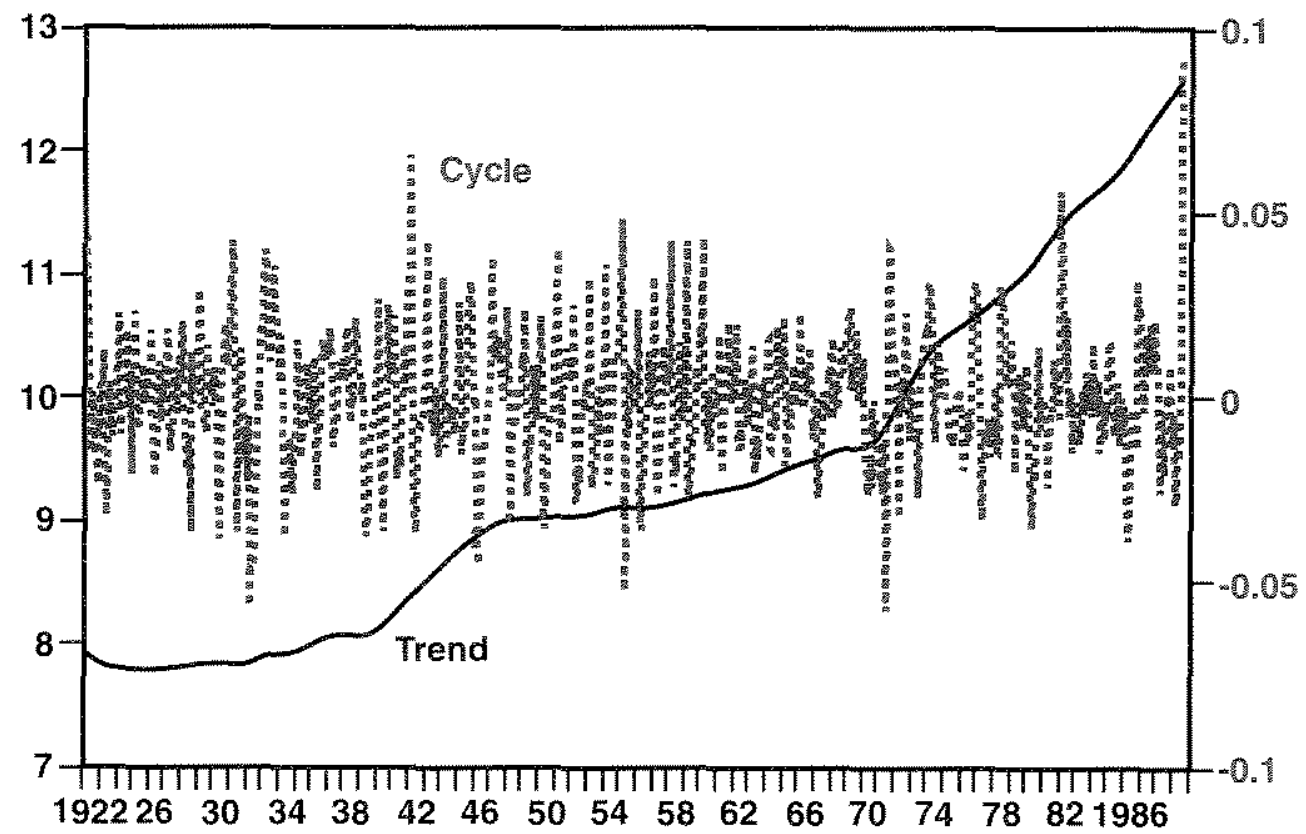


Figure 11

Short Interest Rate Trend and Cycle (1870-1992)

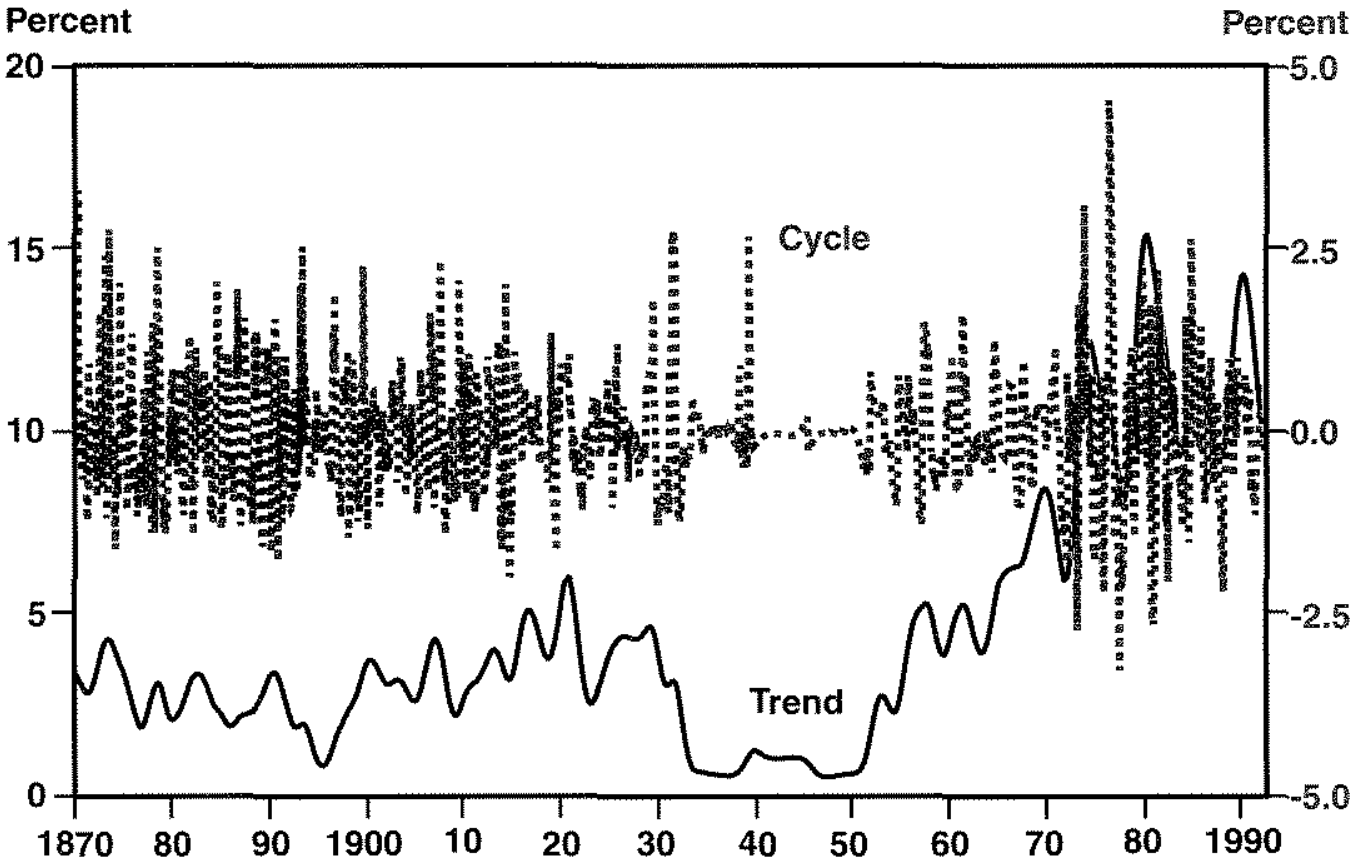

Figure 12

Long Interest Rate Trend and Cycle (1870-1992)

Percent

Percent

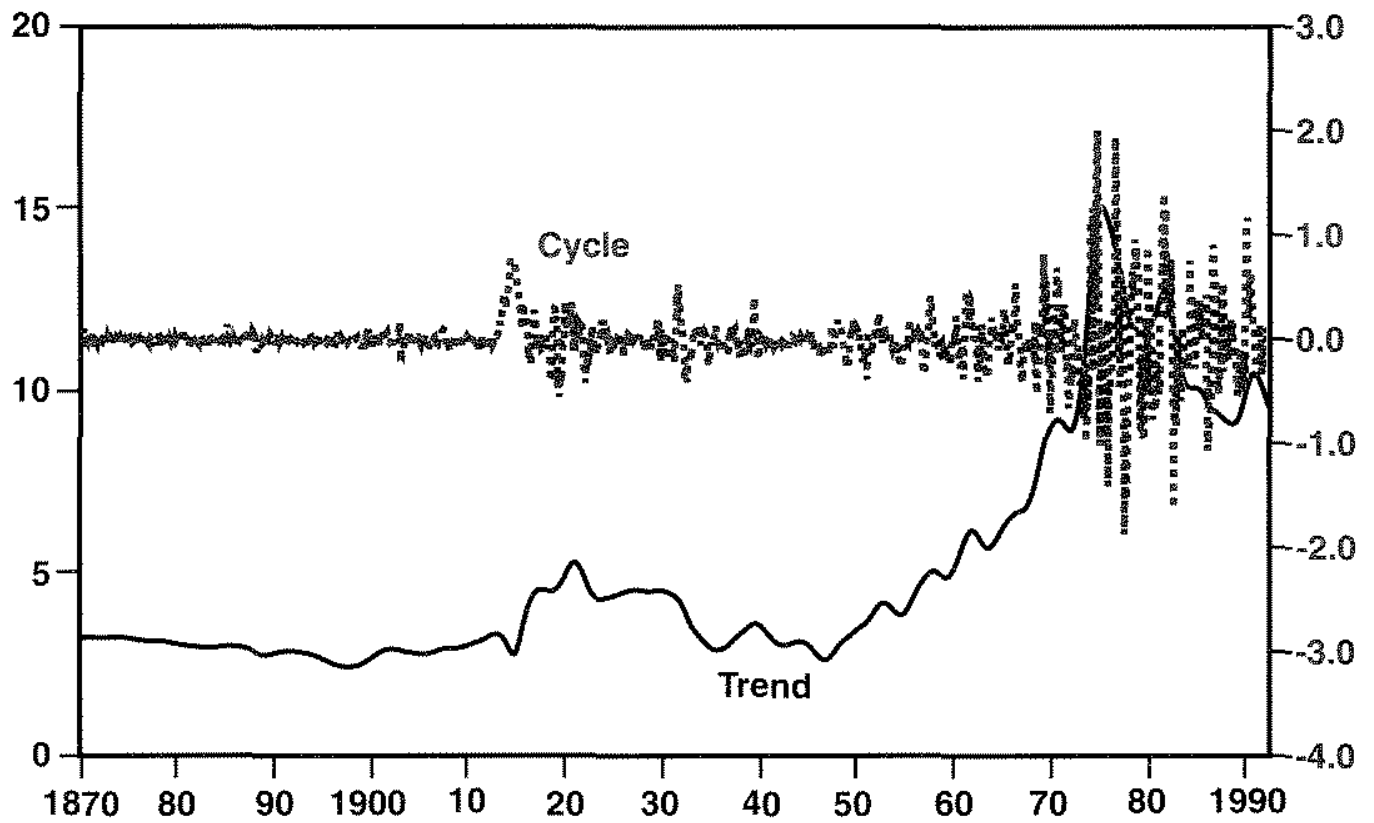


became increasingly credible, the relationship between movements in short- and long-term rates changed. ${ }^{22}$

It cannot but be observed that there was greater stability of output, interest rates and prices under the gold standard than under any subsequent exchange rate regime. But, of course, the gold standard was more than an exchange rate regime. It was a system, a set of rules, for the conduct of monetary policy. As Bordo (1993) wrote, "The gold standard rule can be viewed as a form of contingent rule or a rule with escape clauses. The monetary authority maintains the standard-that is, keeps the price of the currency in terms of gold fixedexcept in the event of a well-understood emer. gency, such as a major war or a financial crisis. In wartime it may suspend gold convertibility and issue paper money to finance its expenditures, and it can sell debt issues in terms of the nominal value of its currency on the under. standing that debt will eventually be paid off in gold. The rule is contingent in the sense that the public understands that the suspension will last only for the duration of the wartime emergency plus some period of adjustment. It assumes that afterward the government will follow the deflationary policies necessary to resume payments at the original parity." It may be consistent with this interpretation of the gold standard that with the floating exchange rate of the 1970s, output variability fell, but not to where it had been under the gold standard. The argument would be that monetary policy was now clearly focused on internal objectives and not subject to the vicissitudes of a multitude of shocks from the outside world.

All in all, then, it appears clear that the exchange rate regime in the United Kingdom has not been a source of volatility for the main macroeconomic variables. For that reason we need not consider why exchange rate regimes might affect real economic performance-m the United Kingdom they did not. The case for a fixed rate regime in the United Kingdom apparently must depend only on its traditional source of suppont - the desire to import price level performance.

It is, of course, important to consider whether these results generalize to other economies.

\footnotetext{
${ }^{22}$ Initially, rises in short-term rates produced rises in longterm rates. But as markets became convinced that the authorities were serious, short and long-term rates started to move much more independently of each other.
}

There is virtually no feature of the U.K. econo. my to indicate that they should not." The com. position of output is not umusual; the U.K. economy has always been fairly open. It was a dominant economy internationally for only a modest part of our period, and it has not gone through hyperinflation or recessions as severe as those in some other economies, so such problems cannot have biased our results. Though we would not claim that our findings are more than those of a case study, we would suggest that they are findings we would not be surprised to see roughly repeated in studies of other countries.

\section{REFERENCES}

Aschheim, Joseph, Martin J. Bailey and George S. Tavas. "Dollar Variability, the New Protectionism, Trade and Financial Performance," in Dominick Salvatore, ed., The New Protectionist Threat to World Welfare (NorthHolland 1987), pp. 424-49.

Bailey, Martin J., George S. Tavlas and Michael Ulan. "Exchange Rate Variability and Trade Performance: Evidence for the Big Seven Industrial Countries;" Weltwitch Archiv (Volume 122,1986), pp. 466-77.

"The Impact of Exchange-Rate Volatility on Export Growth: Some Theoretical Considerations and Empirical Results," Journal of Polficy Modeling (Spring 1987), pp. 225-43.

Barro, Robert J. "Money and the Price Level Under the Gold Standard," Economic Joumal (March 1979), pp. 13-33.

Batchelor, Roy A., and Geoffrey E. Wood. "Floating Exchange Rates: The Lessons of Experience," in Roy A. Batchelor and Geofrey $E$. Wood, eds., Exchange Rate Policy (St. Martin's Press, 1982), pp. 12-34.

Belongia, Michael T. "Prospects for International Policy Coordination: Some Lessons for the EMS," this Review (July/August 1988), pp. 19-27.

Bordo, Michael D. "The Gold Standard, Bretion Woods, and Other Monetary Regimes: A Historical Appraisal," this Review (March/April 1993), pp. 123-87.

Bryant, Ralph C. International Financial intermediation (The Brookings institution, 1987).

Cagan, Phillip. "Mr. Gibson's Paradox-Was it There?" in Michael D. Bordo and Anna J. Schwartz, eds., A Retrospective on the Classical Gold Standard, $1821-1931$ (Univer. sity of Chicago Press, 1984), pp. 604-10.

Capie, Forrest H., Terence C. Mills and Geoffrey E. Wood. "What Happened in 1931?" in Forfest H. Capie and Geoftrey E. Wood, eds., Financial Crises and the World Banking System (St, Martin's Press, 1986a), pp. 120-48.

${ }^{23}$ This is also suggested by the similar structure of models used to explain and predict the economies of a wide range of countries. 
"Debt Management and Interest Rates: the British Stock Conversion of 1932," Applied Economics (Volume 18, 1986b), pp. $111 \div-26$

Capie, Forrest H., and Geoffrey E. Wood. "Money in the Economy, 1870 1939" in Roderick Floud and Donald McClosky, eds., An Economic History of Britain (Cambridge University Press, forthcoming).

Cushman, David O. "The Etfects of Real Exchange Rate Risk on International Trade," Journal of International Economics (August 1983), pp. 45-63.

deGrauwe, Paul, and Bernard deBellefroid. "Long-Run Exchange Rate Varability and International Trade," in Sven Arndt and J. David Richardson, eds, Real Financial Linkages Among Open Economies (MIT Press, 1987). pp. 193-212.

Feldstein, Martin. "The Case Against EMU," The Economist (June 13, 1992), pp. 19-22.

Fisher, Irving. The Theory of Interest (Macmilian, 1930).

Friedman, Milton, and Anna J. Schwartz. Monetary Trends in the Unifed States and the United Kingdom (University of Chicago Press, 1982).

Gotur, Padma. "Effects of Exchange Rate Volatility on Trade: Some Futher Evidence," IMF Staff Papers (September 1985), pp. $475-512$.

Haberler, Gottfried. "The International Monetary System," The AET Economist (July 1986).

Harvey, A.C., and Alfred Jaeger. "Detrending, Stylized Facts and the Business Cycle" London School of Economics Discussion Paper No. EM/91/230, 1991.

Hodrick, Robert J., and Edward C. Prescott. "Postwar U.S. Business Cycles: An Empirical Investigation," CarnegieMellon University Discussion Paper No. 451 (1980).

Hume, David. "Of the Balance of Trade, " in Eugene Rotwein, ed., David Hume, Writings on Economics (The University of Wisconsin Press, 1970), pp. 60-77.

International Monetary Fund. "Exchange Rate Volatility and World Trade," Occasional Paper No. 28 (1984)
King, Robert $G_{\text {, }}$ and Sergio Rebelo. "Low Frequency Filtering and Real Business Cycles:" University of Rochester Working Paper No. 205 (1989).

Kyland, Finn E., and Edward C. Prescott. "Business Cycles: Real Facts and a Monetary Myth:" Federal Reserve Bank of Minneapolis Quarterly Review (Spring 1990), pp. 3-18.

Mills, Terence C. "Are Fluctuations in UK. Output Transitory or Permanent?" Manchester School of Business (Volume $59,1991)$, pp. 1-11.

"A Note on the Gibson Paradox Duting the Gold Standard," Explorations in Economic History (July 1990), pp. $277 \div 86$

Mills, Terence C., and Geoffrey E. Wood. "Capital Flows and the Excess Burden of the Exchange Rate Regime," Hull Economic Research Paper (1993).

"Econometric Evaluation of Alternative Money Stock Series, 1880-1913," Journal of Money, Credit and Banking (May 1982), pp. 265-77.

"Money and Interest Rates in Britain From 1870-1913," in Nick Crafts and Stephen Broadberry, eds., Britain in the international Economy 1870-1939 (Cambridge University Press, 1992), pp. 199-217.

Rockoff, Hugh. "Some Evidence on the Real Price of Gold, its Costs of Production, and Commodity Prices," in Michael D. Bordo and Anna J. Schwartz, eds., A Retrospective on the Classical Gold Standard, 1821-1931 (The University of Chicago Press, 1984), pp. 613-44.

Schumpeter, Joseph Alois. Capitalism, Socialism, and Democracy, 3ro ed. (Harper, 1950).

Wiltiamson, John, and Geoffrey E. Wood. "The British Inflation: Indigenous or Imported?" American Economic Review (September 1976), pp. 520-3t.

Wood, Geoffrey E. "The European Monetary System: Past Developments, Future Prospects and Economic Rationale," in Richard Jenkins, ed., Britain and the EEC (Macmilan 1983).

\section{Appendix \\ The Hodrick-Prescott Filter}

The filter proposed by Hodrick and Prescott (1980) has a long tradition as a method of fitting a smooth curve through a set of points, ver. sions of it being used as an actuarial graduation formula. Given the traditional decomposition $y_{t}=\mu_{t}+n_{t^{\prime}}$ the trend series $\mu_{t}$ is obtained as the solution to the problem of minimizing

(1) $\sum_{t=1}^{T}\left[y_{t}-\mu_{t}\right]^{2}+\lambda \sum_{i=1}^{T}\left[\left(\mu_{t}-\mu_{t-\lambda^{\prime}}\right)-\left(\mu_{t+1},-\mu_{t}\right)\right]^{2}$

with respect to $\mu_{y^{\prime}} \mu_{z}, \ldots, \mu_{T^{*}}$ The first order condition for this minimization problem is
(2) $y_{t}=\lambda\left[\mu_{t+z}-4 \mu_{t+1}+(6+\lambda-7) \mu_{t}-4 \mu_{t-1}+\mu_{1+2} \mathrm{I}\right.$

Using the lag operator $B$, defined such that $B^{j} \mu_{f} \equiv \mu_{t-j}$, this can be written as

$$
\text { (3) } \begin{aligned}
Y_{t} & =\lambda\left[B^{-2}-4 B^{-1}+\left(6+\lambda^{-1}\right)-4 B+B^{2}\right] \mu_{t} \\
& =\lambda\left[(1-B)^{2}\left(1-B^{-1}\right)^{2}+\lambda^{-1}\right] \mu_{t}
\end{aligned}
$$

so that if an infinite series of $y$ values were available, $\mu_{t}$ would be given by the two-sided moving average

(4) $\mu_{i}=\sum_{j=-\infty}^{\infty} \alpha_{j} Y_{t-j}, \alpha_{j}=\alpha_{-j}$ 
where the weights can be calculated from

(5) $\alpha(B)=\left[\lambda(1-B)^{2}\left(1-B^{-1}\right)^{2}+1\right]^{-1}$.

King and Rebelo (1989) provide expressions for the $\alpha_{j^{\prime}}$ which do not take a simple form. Fortunately, Hodrick and Prescott (1980) provide an algorithm that removes the need to calculate the moving average weights and so allows the trend to be computed when only a finite number of y observations are available. This algorithm was employed to compute the decompositions used here, noting that the cyclical component can be obtained by residual as $n_{1}=y_{i}-\mu_{i}$. Typically, following Hodrick and Prescott, $\lambda$ is set at 100 if annual data are used or 1,600 if quarterly or monthly data are used. ${ }^{1}$

Harvey and Jaeger (1991), for example, show that the filter $\alpha(B) y$, can be interpreted as being the optimal estimate of $\mu_{t}$ when $y_{t}$ is generated by the structural model

(6)

$$
\begin{aligned}
& y_{i}=\mu_{i}+n_{i} \\
& \mu_{t}=\mu_{t \cdots 1}+\Psi_{t-t} \\
& \psi_{t}=\Psi_{t-1}+\xi_{t} \\
& n_{t}^{\sim} N I D\left(0, \sigma_{\pi}^{2}\right), \zeta_{t} N I D\left(0, \sigma_{\xi}^{2}\right), \lambda=\sigma_{n}^{2} / \sigma_{\xi}^{2}
\end{aligned}
$$

An observed series may not be generated even approximately by such a model, and even if it is, the ratio of the two innovation variances may be very different from the assumed value of $\lambda$. Harvey and Jaeger argue that the HodrickPrescott filter may create spurious cycles, distort the estimates of the components or both. King and Rebelo argue in similar vein, atthough they focus on the calculation of sample moments of the estimated trend and cycle components. Given these strictures, we emphasize that our use of the filter is purely for exploratory purposes outside the confines of any explicit model. 